\title{
ASSOCIATION OF TOBACCO DEPENDENCE, ALCOHOLISM AND ANABOLIC STEROIDS WITH MENISCOLIGAMENTOUS INJURIES
}

\section{ASSOCIAÇÃO DE TABAGISMO, ALCOOLISMO E ANABOLIZANTES ÀS LESÕES MENISCO-LIGAMENTARES}

\author{
Diego Costa Astur ${ }^{1}$, Igor Neves Sbampato ${ }^{1}$, Gustavo Gonçalves Arlian ${ }^{1}$, Carlos Eduardo da Silveira Franciozi ${ }^{1}$, \\ Pedro DebieuX ${ }^{1}$, Molses COHEN ${ }^{1}$
}

1. Sports Traumatology Center (CETE), Department of Orthopedics and Traumatology (DOT), Universidade Federal de São Paulo (UNIFESP), São Paulo, SP, Brazil.

\section{ABSTRACT}

Objective: To determine a relationship between smoking, alcohol abuse and anabolic steroids and meniscoligamentous injuries. Methods: A total of 239 patients underwent surgical treatment of isolated anterior cruciate ligament (ACL) lesion, $A C L$ associated with meniscal injury and isolated meniscal injury, and were inquired by a single team of surgeons about their habits: smoking, alcoholism and use of artificial anabolic agents. In addition, quality of life was assessed using the SF-36 questionnaire. Results: It was not possible to establish a direct relationship between habits and meniscal and ligamentous injuries, despite the finding that patients with $\mathrm{ACL}$-associated lesions were more frequently smokers, and that patients with isolated meniscal injuries used more artificial anabolic agents. Regarding quality of life, there were no statistical differences in the habits between the groups; however, except for smokers with isolated meniscal injury, all patients who did not have the habits analyzed presented a better score in the SF-36 questionnaire. Conclusion: There were no significant findings correlating smoking, alcohol abuse and artificial anabolic agents with the presence of injuries. In addition, six months after the surgical treatment, there was no difference in the quality of life between the groups evaluated. Level of Evidence III, Prospective case series.

Keywords: Smoking. Alcoholism. Anabolic agents. Anterior Cruciate Ligament. Meniscus.

\section{RESUMO}

Objetivo: Determinar uma relação entre hábito de fumar, abuso de álcool e anabolizantes artificiais com lesões menisco-ligamentares do joelho. Métodos: Um total de 239 pacientes foi submetido ao tratamento cirúrgico de lesão isolada do ligamento cruzado anterior (LCA), do LCA associada à lesão meniscal e lesão meniscal isolada e foi indagado, por uma única equipe de cirurgiões, sobre seus hábitos: tabagismo, alcoolismo e uso de anabolizantes artificiais. Além disso, foi avaliada a qualidade de vida com o questionário SF-36. Resultados: Não foi possível estabelecer uma relação direta entre os hábitos e as lesões menisco-ligamentares, apesar da constatação de que os pacientes com lesões associadas ao LCA eram, com maior frequência, tabagistas e que os pacientes com lesão meniscal isolada usavam mais anabolizantes artificiais. Com relação à qualidade de vida, não houve diferença estatística quanto aos hábitos entre os grupos, porém, exceto tabagistas com lesão meniscal isolada, todos os pacientes que não tinham os hábitos analisados apresentaram pontuação melhor no questionário SF-36. Conclusão: Não houve achados significativos que correlacionassem os hábitos de fumar, abuso de álcoole anabolizantes artificiais com a presença de lesão. Além disso, seis meses após o tratamento cirúrgico, não houve diferença na qualidade de vida entre os grupos avaliados. Nível de evidência III, Tipo de estudo: série de casos prospectivos.

Descritores: Tabagismo. Alcoolismo. Anabolizantes. Ligamento cruzado anterior. Menisco.

Citation: Astur DC, Sbampato IN, Arliani GG, Franciozi GES, Debieux P, Cohen M. Association of tobacco dependence, alcoholism and anabolic steroids with meniscoligamentous injuries. Acta Ortop Bras. [online]. 2018;26(4):236-9. Available from URL: http://www.scielo.br/aob.

\section{INTRODUCTION}

The most commonly injured structures of the knee are the anterior cruciate ligament (ACL) and the menisci, generally affecting active young individuals. The ACL is an important primary stabilizer, whose main function is to restrict the anteriorization and internal rotation of the tibia. ${ }^{1}$ The menisci consist of fibrocartilaginous structures composed mainly of type I collagen, whose most important functions are as follows: load transmission, increase in joint conformity and synovial fluid distribution. Therefore, it is evident that injuries to such structures cause functional deficits or painful conditions. ${ }^{2}$ It is known that there are several predisposing factors for injury involving these structures. A number of studies have correlated a higher incidence of ACL tears to patients' intrinsic characteristics, such as intercondylar fossa stenosis ${ }^{3}$ and female sex. ${ }^{4}$ Some

All authors declare no potential conflict of interest related to this article. 
studies seek to correlate extrinsic factors with meniscoligamentous injuries. According to Gregory et al., ${ }^{5}$ patients with a history of ACL tears and high body mass index (BMI) present with a higher rate of contralateral injuries or revision of the reconstruction of this previously injured ligament. ${ }^{6}$

Lifestyle habits such as smoking, alcoholism and anabolic steroid use, either in combination or individually, are present in the daily lives of millions of individuals. Because they are changeable factors, unlike the width of the intercondylar notch and the sex of the individual, it is necessary to observe their potential to influence orthopedic knee injuries, especially those involving the menisci and ligaments.

The aim of this study is to observe the relationship between meniscoligamentous injuries and the presence of the habits of smoking, alcoholic beverage consumption and prior use of artificial steroids. In addition, these habits were correlated with the patients' quality of life, using the SF-36 questionnaire.

\section{MATERIALS AND METHODS}

This is a prospective and observational study of patients operated on for the treatment of meniscoligamentous injuries between 2010 and 2015. All patients included in the research project signed the informed consent form, agreeing to participate in the study, which was evaluated and approved by the Institutional Review Board (IRB) of the Universidade Federal de São Paulo (UNIFESP).

The inclusion criteria were skeletally mature patient; indication for $\mathrm{ACL}$ surgery associated or not associated with the meniscal injury, and isolated meniscal injury. The non inclusion criteria were presence of other associated injuries; involvement of the contralateral limb due to other meniscoligamentous injuries, and presence of systemic diseases. The patients were assessed by a single team of orthopedic surgeons and, through indication for surgery due to ACL lesions associated or not associated with meniscal injuries, were questioned about their lifestyle habits, including: smoking, alcohol consumption and anabolic steroid use. In addition, a quality of life assessment questionnaire (SF 36) was applied after 6 months of treatment. Statistical correlation was applied to the data obtained and the incidence of injuries, along with the potential deleterious effects of these habits on the injured patient.

Once included, the patients were divided into three groups according to the type of injury: group 1, ACL injury; group 2, associated ACL and meniscal injuries; group 3, isolated meniscal injuries.

\section{Statistical analysis}

Parametric statistical tests were used because the data are quantitative and continuous. In order to verify if two determined variables and/or their levels were statistically significant, we tested for equality of two proportions. We used the Chi-Square test to verify whether two variables and their levels have statistical dependence (association) or not. Differences with $p<0.05$ were considered statistically significant. All confidence intervals constructed throughout the study had 95\% statistical confidence.

\section{RESULTS}

The study included 239 patients who agreed to participate. Of these, 107 patients had an isolated ACL injury (group 1), 72 an ACL tear associated with the meniscal injury (group 2), and 60 cases had an isolated meniscal injury (group 3). The majority of the patients were male, 196 patients (82\%) and 145 patients (60.7\%) were white (Caucasian). The mean age was 33 years, ranging from 10 to 72 years with patients in their 30s prevailing. Upon analyzing Body Mass Index (BMI), we found that the majority of patients, $50.2 \%$, were overweight, i.e., with a BMI value between 25 and $29.9 \mathrm{~kg} / \mathrm{m}^{2}$ (Table 1).
Regarding the subjects' lifestyle habits, 51 patients were smokers (21.34\%), 189 alcoholic beverage consumers (79.1\%), considered regular or social drinkers, and $5.86 \%$ (14 cases) of patients reported previous use of anabolic steroids. When assessing the incidence of studied habits by group, the proportion was maintained and no statistical differences were found (Table 2).

There was no statistical difference between the presence of the habits and the group studied, but there was a tendency for patients from group 2 to smoke more frequently $(p=0.086)$. Likewise, the use of anabolic steroids showed a strong tendency for the group of isolated meniscal injuries (group 3$)(p=0.055)$ (Figure 1).

Six months after surgical treatment, the groups did not exhibit any significant differences in their quality of life (according to the SF-36 questionnaire), when compared with the habit evaluated. However, it was noted that with the exception of the score of the smokers in group 3, subjects in all the groups who did not have the habit evaluated had a higher average score (Table 3).

Table 1. Distribution of the sample between the groups and their characteristics: sex, age, ethnicity and BMI.

\begin{tabular}{c|c|c|c|c|c}
\hline & Variable & G1 & G2 & G3 & Total \\
\hline \multirow{2}{*}{ Sex } & Male & $86(80.4 \%)$ & $56(77.8 \%)$ & $54(90 \%)$ & $196(82 \%)$ \\
\cline { 2 - 6 } & Female & $21(19.6 \%)$ & $16(22.2 \%)$ & $6(10 \%)$ & $43(18 \%)$ \\
\hline Age & mean (min-max) & $31(10-56)$ & $31(14-58)$ & $39(14-72)$ & $33(10-72)$ \\
\hline \multirow{4}{*}{ Ethnicity } & White & $(73) 68.2 \%$ & $(39) 54.2 \%$ & $(33) 55 \%$ & $(145) 60.7 \%$ \\
\cline { 2 - 6 } & Mixed Race & $(25) 23.4 \%$ & $(23) 31.9 \%$ & $(18) 30 \%$ & $(66) 27.6 \%$ \\
\cline { 2 - 6 } & Black & $(9) 8.4 \%$ & $(10) 13.9 \%$ & $(9) 15 \%$ & $(28) 11.7 \%$ \\
\hline \multirow{5}{*}{ BMI } & below & $1(0.93 \%)$ & 0 & 0 & $1(0.42 \%)$ \\
\cline { 2 - 6 } & normal & $38(35.51 \%)$ & $24(33.33 \%)$ & $23(38.33 \%)$ & $85(35.56 \%)$ \\
\cline { 2 - 6 } & overweight & $51(47.67 \%)$ & $40(55.56 \%)$ & $29(48.33 \%)$ & $120(50.2 \%)$ \\
\cline { 2 - 6 } & obesity & $17(15.89 \%)$ & $8(11.11 \%)$ & $8(13.34 \%)$ & $33(13.82 \%)$ \\
\hline
\end{tabular}

Table 2. Characteristics of the groups in terms of the habits assessed.

\begin{tabular}{c|c|c|c|c|c}
\hline & Variable & G1 & G2 & G3 & Total \\
\hline \multirow{2}{*}{$\begin{array}{c}\text { Anabolic } \\
\text { Steroid Use }\end{array}$} & No & $90.70 \%$ & $95.80 \%$ & $98.30 \%$ & \multirow{2}{*}{$\mathrm{P}>0.05$} \\
\cline { 2 - 5 } & Yes & $9.30 \%$ & $4.20 \%$ & $1.70 \%$ & \\
\hline \multirow{3}{*}{ Smoking } & No & $84.1 \%$ & $73.60 \%$ & $75.00 \%$ & \multirow{2}{*}{$\mathrm{P}>0.05$} \\
\cline { 2 - 5 } & Yes & $15.90 \%$ & $26.40 \%$ & $25.00 \%$ & \\
\hline \multirow{4}{*}{ Drinking } & Never & $23.40 \%$ & $22.2 \%$ & $15 \%$ & \multirow{2}{*}{$\mathrm{P}>0.05$} \\
\cline { 2 - 5 } & Regularly & $8.40 \%$ & $4.20 \%$ & $8.30 \%$ & \\
\cline { 2 - 5 } & Socially & $68.20 \%$ & $73.60 \%$ & $76.70 \%$ & \\
\hline
\end{tabular}

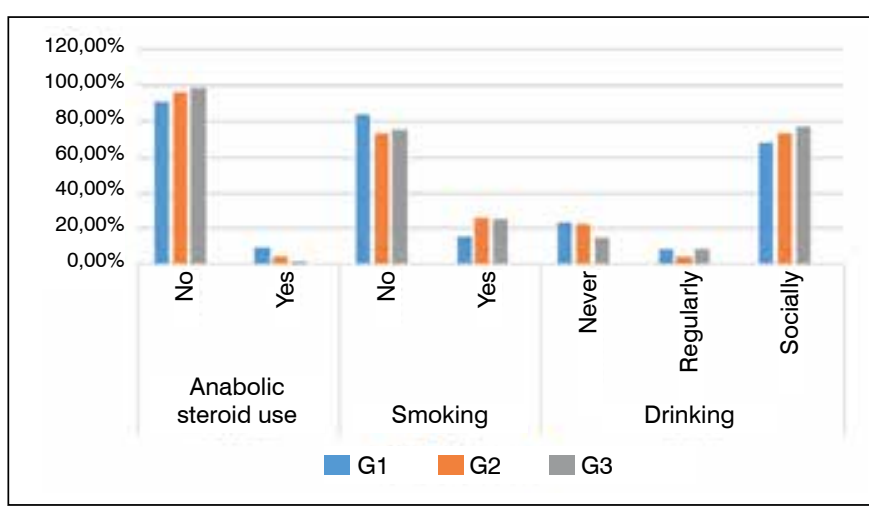

Figure 1. Prevalence of habits between the groups. 
Table 3. Score obtained in the SF-36 questionnaire to assess patient's quality of life 6 months after surgery, according to the patient's group (there was no statistical difference for all habits assessed, $p>0.05$ ).

\begin{tabular}{|c|c|c|c|c|c|c|c|c|c|}
\hline & & & Mean & SD & Min & Max & $\mathrm{N}$ & $\mathrm{Cl}$ & $p$ \\
\hline \multirow{7}{*}{ Group 1} & \multirow{3}{*}{ Drinking } & Never & 110.3 & 15.6 & 76.6 & 139.8 & 23 & 6.4 & \multirow{3}{*}{0.299} \\
\hline & & Regularly & 108.4 & 16.8 & \begin{tabular}{|l|}
79.5 \\
\end{tabular} & 129.5 & 9 & 11 & \\
\hline & & Socially & 108.4 & 18.1 & 11.6 & 134.2 & 69 & 4.3 & \\
\hline & \multirow{2}{*}{ Smoking } & No & 109.6 & 17.7 & 11.6 & 134.2 & 84 & 3.8 & \multirow{2}{*}{0.299} \\
\hline & & Yes & 104.8 & 15.2 & \begin{tabular}{|l|}
85.8 \\
\end{tabular} & 139.8 & 17 & 7.2 & \\
\hline & \multirow{2}{*}{$\begin{array}{c}\text { Anabolic } \\
\text { Steroid Use }\end{array}$} & No & 108.9 & 17.5 & 11.6 & 139.8 & 93 & 3.6 & \multirow{2}{*}{0.843} \\
\hline & & Yes & 107.7 & 16.3 & 86.5 & 125.4 & 8 & 11.3 & \\
\hline \multirow{7}{*}{ Group 2} & \multirow{3}{*}{ Drinking } & Never & 119.5 & 12.9 & 88.6 & 135.4 & 13 & 7 & \multirow{3}{*}{0.211} \\
\hline & & Regularly & 112.1 & 21.8 & 89.6 & 133.1 & 3 & 24.7 & \\
\hline & & Socially & 110.4 & 11.6 & 84.5 & 130.2 & 51 & 3.2 & \\
\hline & \multirow{2}{*}{ Smoking } & No & 113.4 & 13.2 & 84.5 & 135.4 & 49 & 3.7 & \multirow{2}{*}{0.211} \\
\hline & & Yes & 109 & 10.8 & 88.5 & 132 & 18 & 5 & \\
\hline & \multirow{2}{*}{$\begin{array}{c}\text { Anabolic } \\
\text { Steroid Use }\end{array}$} & No & 112.3 & 12.8 & 84.5 & 135.4 & 64 & 3.1 & \multirow{2}{*}{0.896} \\
\hline & & Yes & 111.3 & 11.2 & 104.1 & 124.2 & 3 & 12.7 & \\
\hline \multirow{7}{*}{ Group 3} & \multirow{3}{*}{ Drinking } & Never & 113.9 & 13.7 & 97.5 & 138.2 & 8 & 9.5 & \multirow{3}{*}{0.093} \\
\hline & & Regularly & 106.6 & 16.3 & 83.5 & 121.1 & 4 & 15.9 & \\
\hline & & Socially & 107.8 & 14.5 & 76.2 & 132.1 & 41 & 4.4 & \\
\hline & \multirow{2}{*}{ Smoking } & No & 107.1 & 15.3 & \begin{tabular}{|l|}
76.2 \\
\end{tabular} & 138.2 & 41 & 4.7 & \multirow{2}{*}{0.093} \\
\hline & & Yes & 114.8 & 9.8 & 101.5 & 129.6 & 13 & 5.3 & \\
\hline & \multirow{2}{*}{$\begin{array}{c}\text { Anabolic } \\
\text { Steroid Use }\end{array}$} & No & 109.4 & 14.3 & 76.2 & 138.2 & 53 & 3.8 & \multirow{2}{*}{0.118} \\
\hline & & Yes & 86.5 & $x$ & 86.5 & 86.5 & 1 & $x$ & \\
\hline
\end{tabular}

\section{DISCUSSION}

Our results showed that there seems to be no influence between the incidence of meniscoligamentous injuries and smoking, drinking, or anabolic steroid use, although they are related to greater overall morbidity and mortality, ${ }^{7}$ cardiovascular disease ${ }^{8}$ and neoplasia, ${ }^{9}$ for example, when compared to the population free of such influences.

The main mechanism of injury of the meniscoligamentous lesions is due to direct or indirect knee trauma. This fact could justify the lack of a relationship between lifestyle habits and the injuries mentioned here.

The proportion of drinkers, smokers and anabolic steroid users remained the same between the groups, except for the percentage of tobacco-using patients belonging to group 2 and anabolic steroid users belonging to group 3. However, as the data are not consistent we cannot claim a direct correlation between these variables.

Smoking is known to be associated with worse postoperative functional results in ACL reconstructions, as well as delayed bone healing and wound healing capacity. ${ }^{10}$ These deleterious effects are justified by the fact that the products resulting from tobacco combustion cause peripheral tissue hypoxia, cell damage due to the release of free radicals, and vasoconstriction. ${ }^{11}$ Thus, although smoking does not seem to be related to the higher incidence of ligament injuries, patients should be provided with guidance on smoking cessation, since there will be a greater potential for unsatisfactory results in the postoperative period.
Artificial steroids have been used for many decades to gain muscle mass and strength and for performance enhancement. ${ }^{12}$ Their use was initially restricted to professional athletes, but the use of artificial steroids has gradually became commonplace among individuals who take up different types of sport and for aesthetic purposes. ${ }^{12}$ Numerous side effects are known, including cardiovascular disorders ${ }^{12}$ infertility, ${ }^{13}$ hepatotoxicity ${ }_{1}^{14}$ greater propensity to tendon tears ${ }^{15}$ and to develop neoplasms. ${ }^{16}$ This study did not show a relationship between exogenous anabolism and ligament injuries, but steroid users displayed a greater tendency to sustain isolated meniscal injuries. However, it is not possible to say whether this tendency is due to the increase in the frequency of physical activities, in anabolic steroid users, or if it is a direct effect of the drug. Alcohol is one of the most commonly used drugs in the world, either on a regular basis or in a social setting, but has become a serious public health problem, with an estimated 3 million deaths occurring per year due to its use..$^{17}$ Although in our study we found no significant relationship between this habit and the presence of meniscoligamentous injuries, or an objective deterioration in quality of life, numerous undesirable effects have been demonstrably attributed to the use of this drug. These include psychiatric disorders, ${ }^{18}$ hepatotoxicity ${ }^{19}$ and a greater propensity to develop certain neoplasms. ${ }^{20}$ Therefore its use should be discouraged and dependence should be viewed as a health problem and treated as such.

In our study, we were not able to determine a direct relationship between smoking habits, alcoholic beverage consumption and anabolic steroid use with meniscoligamentous injuries, although patients with ACL injuries associated with meniscus rupture smoked more frequently, while subjects with isolated meniscal injuries used anabolic steroids more frequently. In addition, quality of life as assessed by the SF-36 questionnaire did not show any statistical difference, when assessed in relation to the habits of each group; however, note that with the exception of smokers in group 3, all non-smoking patients had higher average scores. Thus, all the habits evaluated should be avoided, since in addition to the numerous side effects already mentioned, quality of life could potentially deteriorate. We should point out some limitations of this study. The patients were assessed 6 months after the surgical treatment, yet we consider it important to make an assessment at different times and to extend the duration of the follow-up for a better assessment of quality of life. We consider this study extremely important, due to the characteristics and size of the sample, as well as the scarcity of studies on the topic in the literature.

\section{CONCLUSIONS}

When assessing patients with ACL injury and/or meniscal injury in terms of smoking and drinking habits and use of artificial steroids, there were no significant results that correlate these variables with the presence of the injury. Moreover, 6 months after the surgical treatment, there was no difference in quality of life between the groups assessed.

\section{ACKNOWLEDGEMENTS:}

Project with support from the Fundação de Apoio à Pesquisa do Estado de São Paulo (FAPESP - Foundation for Support of Research of the State of São Paulo). No. 2012/07721-2

AUTHORS' CONTRIBUTIONS: Each author made significant individual contributions to this manuscript. DA (0000-0001-9163-7979)* and GA (0000-00034371-5041)* were the main contributors in writing the manuscript. Diego Astur, GA (0000-0003-4371-5041)*, PD (0000-0003-3592-6981)*, CF (0000-0002$0932-6870)^{\star}, \mathrm{MC}(0000-0001-7671-8113)^{*}$ performed the surgery, monitored the patients and collected clinical data. DA (0000-0001-9163-7979)* and PD $(0000-0003-3592-6981)^{\star}$ assessed the data from the statistical analysis. DA (0000-0001-9163-7979)*, GA (0000-0003-4371-5041)* and CF (0000-00020932-6870)* performed the bibliographic search and revision of the manuscript, and contributed to the intellectual concept of the study. ${ }^{*}$ ORCID (Open Researcher and Contributor ID). 


\section{REFERENCES}

1. Amis AA, Dawkins GPC. Functional anatomy of the anterior cruciate ligament. Fibre bundle actions related to ligament replacements and injuries. J Bone Joint Surg Br. 1991;73(2):260-7.

2. Renstrom $\mathrm{P}$, Johnson RJ. Anatomy and biomechanics of the menisci. Clin Sports Med. 1990;9(3):523-38.

3. Souryal TO, Freeman TR. Intercondylar notch size and anterior cruciate ligament injuries in athletes. A prospective study. Am J Sports Med. 1993;21(4):535-9.

4. Schmitz RJ, Ficklin TK, Shimokochi Y, Nguyen AD, Beynnon BD, Perrin DH, et al. Varus/Valgus and Internal/External Torsional Knee Joint Stiffness Differs between Sexes. Am J Sports Med. 2008;36(7):1380-8.

5. Maletis GB, Inácio MCS, Funahashi TT. Risk factors associated with revision and contralateral anterior cruciate ligament reconstructions in the Kaiser Permanent ACLR registry. Am J Sports Med. 2015;43(3):641-7.

6. Bowers AL, Spindler KP, McCarty EC, Arrigain S. Height, weight, and BMI predic intra-articular injuries observed during $A C L$ reconstruction: evaluation of 456 cases from a prospective ACL database. Clin J Sport Med. 2005;15(1)9-13.

7. Adhikari B, Kahende J, Malarcher A, Pechacek T. Annual smoking-attributable mortality, years of potential life lost and productivity losses United States 20012004. CDC. 2008;57(45):1226-8

8. Hurley SF. Short-term impact of smoking cessation on myocardial infarction and stroke hospitalisations and costs in Australia. Med J Aust. 2005;183(1):13-7.

9. Strand TE, Malayeri C, Eskonsipo PK, Grinsrud TK, Norstein J, Grotmol T. [Teenage smoking and lung cancer incidence in early adult age, 1954-1998.] Tidsskr Nor Laegeforen. 2005;125(9):1174-6.

10. Wong LS, Martins-Green M. Firsthand cigarette smoke alters fibroblast migration and survival: implications for impaired healing. Wound Repair Regen. 2004;12(4):471-84.

11. Misery L. Nicotine effects on skin: are they positive or negative? Exp Dermatol. 2004;13(11):665-70.
12. Abidollani F, Joukar S, Najafipour H, Karimi A, Masumi Y, Bindeji F. The risk of life-threatening ventricular arrhythmias in presence of high-intensity endurance exercise along with chronic administration of nandrolone decanoate. Steroids. 2016;105:106-12.

13. Nieschlaq E, Vorona E. Mechanisms in Endocrinology: Medical consequences of doping with anabolic androgenic steroids: effects on reproductive functions. Eur J Endocrinol. 2015;173(2):R47-58.

14. Bond P, Llewellyn W, Van Mol P. Anabolic androgenic steroid-induced hepatotoxicity. Med Hypotheses. 2016;(93):150-3.

15. Kanayama G, DeLuca J, Meehan WP $3^{\text {rd }}$, Hudson JI, Isaacs S, Baggish A, et al. Rupture Tendon in Anabolic-Androgenis Steroid Users: a Cross-Sectional Cohort Study. Am J Sports Med. 2015;43(11):2638-44.

16. Solbach P, Potthoff A, Raatschen HJ, Soudbah B, Lehmann U, Schneider A, et al. Testosterone-receptor positive hepatocellular carcinoma in a 29-year old bodybuilder with a history of anabolic androgenic steroid abuse: a case report. BMC Gastroenterol. 2015;20:15-60.

17. Stickel F, Moreno C, Hampe J, Morgan MY. The genetics of alcohol dependence and alcohol-related liver disease. J Hepatol. 2017;66(1):195-211.

18. Jung J, Galdstein RB, Grant BF. Association of respondent psychiatric comorbidity with family history comorbidity: Results from the National Epidemiologic Survey on Alcohol and Related Conditions-III. Compr Psychiatirc. 2016;(71):49-56.

19. Mani V, Arivalagan S, Siddique AI, Namasivayam IV. Antioxidante and antiinflammatory role of zingerone in ethanol-induced hapatotoxicity. Mol Cell Biochem. 2016;421(1-2):169-81.

20. Latvala J, Hietala J, Koivisto H, Jarvi K, Anttila P, Niemela O. Immune Responses to Ethanol Metabolites and Cytokine Profiles Differenciate Alcoholics with or without Liver Disease. Am J Gastroenterol. 2005;100(6):1303-10. 